\title{
School leadership effects revisited: a review of empirical studies guided by indirect-effect models
}

\author{
M.A. Hendriks* and J. Scheerens \\ Faculty of Behavioural Sciences, University of Twente, Enschede, The Netherlands
}

\begin{abstract}
Fourteen leadership effect studies that used indirect-effect models were quantitatively analysed to explore the most promising mediating variables. The results indicate that total effect sizes based on indirect-effect studies appear to be low, quite comparable to the results of some meta-analyses of direct-effect studies. As the earlier indirect-effect studies tended to include a broad range of mainly school organisational conditions as intermediary variables, more recent studies focus more sharply on instructional conditions. The results of the conceptual analysis and the quantitative research synthesis would seem to support conceptualising educational leadership as a detached and 'lean' kind of meta-control, which would make maximum use of the available substitutes and self-organisation offered by the school staff and school organisational structural provisions. The coupling of conceptual analysis and systematic review of studies driven by indirect-effect models provides a new perspective on leadership effectiveness.
\end{abstract}

Keywords: school leadership; indirect-effect studies; intermediate variables; student achievement

\section{Conceptualisation}

As an introduction to the review and quantitative synthesis of school leadership effects the development of leadership concepts and research models will be briefly reviewed.

\section{From direct to indirect-effect models}

Earlier reviews of leadership effects were based on so-called 'direct' effects of leadership on student performance outcomes (e.g. Witziers, Bosker, and Krüger 2003). Basically, simple correlations between leadership characteristics and student achievement, sometimes adjusted for student background characteristics, were at the focus of these reviews. Despite the presence of conceptual 'indirect' models of leadership effects, in which the influence of leadership is seen as 'meditated' by school-level conditions, like the model by Bossert et al. (1982), empirical studies that were guided by these models took some time to be realised: one of the first wellknown empirical studies of this nature being the work of Mulford (2003) and Silins and Mulford (2004), the LOSLO project. Characteristics of the school organisation, the school climate and perceptions of teachers' work are examples of the intermediary school conditions addressed in these models. Substantively, it makes

*Corresponding author. Email: m.a.hendriks@utwente.nl 
a lot of sense to see the influence of school leadership behaviour on student outcomes as indirect, and as the result of a hypothetical causal chain, through which school heads directly operate on school organisational and instructional conditions, which in their turn influence student achievement. Methodological tools to study such indirect-effect models are available in path analysis and structural equation modelling. Earlier reviews (e.g. Witziers, Bosker, and Krüger 2003) could only refer to a very limited number of 'indirect effect' studies. In this article we are presenting a quantitative overview of effect sizes of a somewhat larger (but still limited) number of recent studies based on indirect-effect models.

\section{From instructional leadership to integrated leadership}

The conceptual development of school leadership can be interpreted as a gradual broadening of the construct of educational leadership, starting out from a very focused concept of instructional leadership, in the early school effectiveness studies by, among others Edmonds (1979), to a more encompassing perspective, indicated as integrated leadership.

The picture of the instructional leader that emerged from early school effectiveness research is that of the leader as a facilitator and controller of the primary process of teaching and learning. The appearance of such concepts as 'curricular leadership' (Glatthorn 1987, 1997) and 'instructional leadership' (Hallinger 1983), reflects this image. This focused view of instructional leadership is concentrated on only one of the four core leadership practices mentioned by Leithwood, Jantzi, and McElheron-Hopkins (2006), namely managing the instructional programme. In a next phase, these relatively narrow conceptualisations of instructional leadership were broadened gradually; actions and strategies other than those closely related to the primary process of teaching and learning come into view as well. Hallinger (1983), for example, stated that instructional leadership is related to defining a mission for the school, managing curriculum and instruction and promoting a learning climate favourable for student learning. One could see this perspective as an extended version of instructional leadership.

The concept of transformational leadership underlines the role of the school leader in promoting school improvement. This implies a focus on what one could call 'secondary processes' in shaping organisational structure and culture and capacity building of the staff. This concept emphasises that one of the main tasks of school leaders is to initiate processes and structures, within the school, that enable teacher collaboration and participative decision-making. The concept is fuelled by the notion that, in many schools, teachers are autonomous and isolated, implying that school leaders should not intervene directly with curricular and instructional affairs, but rather indirectly by transforming the school culture to facilitate collegial planning, collaboration and experimentation aimed at school improvement. In other words, the main tasks of the school leader should be to create a working environment in which teachers collaborate and identify themselves strongly with the school's mission.

One facet of transformational leadership is empowerment of teachers and participative decision-making. This element comes close to the idea of distributed leadership, where teachers as autonomous professionals are seen as carrying out leadership tasks. 
Finally the term 'integrated leadership' has been coined by several authors, e.g. Leithwood (1992).

Here we shall take a liberal interpretation of integrated leadership and take it as:

- an integration of transformational and instructional leadership, following Marks and Printy's (2003) argumentation that in order to be effective, transformational leadership aimed at school reform requires an additional component directed at teaching and learning;

- more encompassing leadership models, such as developed by authors like Quinn et al. (1996) and Bolman and Deal (1997), that include a broad perspective of organisational effectiveness;

- a view of leadership that emphasises the distribution of coordination and leadership tasks not just among people (as in distributed leadership), but also to structural characteristics of the school organisation. This perspective has been introduced by Heck and Hallinger (2009), as they discuss dynamic theories of organisational processes: 'Dynamic theories of organisational processes seek to describe how changes in organisational structures (e.g. size, hierarchy, staffing) and social-cultural interactions (e.g. organisational culture, decision-making structures, leadership, social networks) influence organisational outcomes over a period of time' (Hallinger and Heck 2009, 105).

A schematic overview of the development in the concept formation on school leadership is presented in Table 1.

\section{Relationship between indirect-effect models and school leadership concepts}

The orientation of the different leadership types points at different school conditions that could be seen as intermediary variables in indirect leadership effect models. As the right hand column of Table 1 illustrates, the definition of the various leadership

Table 1. Concepts of leadership at school.

\begin{tabular}{|c|c|}
\hline Type of leadership & Orientation \\
\hline Instructional leadership & Curriculum and instruction \\
\hline \multirow{3}{*}{$\begin{array}{l}\text { Extended instructional } \\
\text { leadership }\end{array}$} & School mission \\
\hline & Managing the curriculum \\
\hline & Providing learning climate \\
\hline \multirow{5}{*}{$\begin{array}{l}\text { Transformational } \\
\text { leadership }\end{array}$} & Models organisational values \\
\hline & Develops shared mission \\
\hline & Provides intellectual stimulation \\
\hline & Builds consensus \\
\hline & Redesigns organisational structure \\
\hline \multirow{2}{*}{ Integrated leadership } & Conditions supporting school improvement \\
\hline & $\begin{array}{l}\text { Instructional leadership; broader perspectives on organisational } \\
\text { effectiveness; leadership roles 'delegated' to people and } \\
\text { structural coordination mechanisms }\end{array}$ \\
\hline
\end{tabular}


concepts is based on reference to functional domains of the school as an organisation, such as the curriculum, organisational structures, the school climate, the capacity of teachers and so on. Further elaboration is facilitated by the way Leithwood, Jantzi, and McElheron-Hopkins (2006) summarise core functions of school leadership:

(1) Developing a vision and giving direction: identifying and formulating a vision, creating a shared interest, high expectations of performance, promoting the acceptance of group objectives, monitoring organisational performance and communicating.

(2) Understanding and developing people: providing intellectual stimulation, giving individual guidance and setting an example. The school leader builds on the knowledge and skills of teachers and other personnel to achieve the school objectives.

(3) Redesigning the organisation: building on cultures and cooperative processes, managing the environment and working conditions, building and maintaining productive relations with parents and the community, connecting the school with the wider environment.

(4) Managing the teaching and learning programme: creating a productive working environment for both teachers and students, promoting organisational stability, guaranteeing effective leadership with the focus on learning, appointing teachers and supporting staff to implement the curriculum, monitoring school activities and performance.

In recent empirical studies guided by indirect-effect models, a wide range of intermediary variables is being addressed. Theoretically one might expect that, for the choice of intermediary variables, the knowledge base of educational effectiveness would be used (Scheerens 2000; Scheerens et al. 2007; Creemers and Kyriakides 2008). In school and instructional effectiveness studies, variables are identified that have an effect on student achievement. As most of these variables can be influenced by school leaders, they are good candidates for being included in indirect-effect studies of school leadership.

Table 2 matches core leadership functions and educational effectiveness enhancing conditions at school and classroom level.

The table shows that there is a fair match between emphases in school leadership and school factors that have been empirically supported for being positively associated with student achievement. Accordingly, Table 2 provides a conceptual map for conducting leadership effect studies guided by indirect models. Examination of actual empirical research studies will reveal to what extent this framework has also been followed. The causal assumption in Table 2 is that the intentions and behavioural directions of school leaders, targeted at specific domains of school functioning, influence the way these domains are actually functioning and, in their turn, influence student achievement. The empirical test of these theoretical assumptions obviously requires a research design that allows for causal interpretation, including the requirement that leadership behaviour and effectiveness enhancing intermediary school conditions are measured independently. 
Table 2. Leadership functions, leadership behaviours and effectiveness enhancing school conditions.

\begin{tabular}{|c|c|c|}
\hline Leadership functions & Leadership behaviour & $\begin{array}{l}\text { Effectiveness enhancing } \\
\text { factors }\end{array}$ \\
\hline Developing a vision & $\begin{array}{l}\text { External contacts } \\
\text { Buffering } \\
\text { Setting values }\end{array}$ & $\begin{array}{l}\text { Enhanced teaching time } \\
\text { Shared sense of purpose } \\
\text { among teachers } \\
\text { High expectations }\end{array}$ \\
\hline $\begin{array}{l}\text { Managing the teaching and } \\
\text { learning programme }\end{array}$ & $\begin{array}{l}\text { Direction setting (vision, goals, } \\
\text { standards) } \\
\text { Monitors curriculum and } \\
\text { instruction (managing the } \\
\text { instructional programme) } \\
\text { Redesigning the organisation }\end{array}$ & $\begin{array}{l}\text { Clear goals and standards } \\
\text { Opportunity to learn } \\
\text { Student monitoring \& } \\
\text { feedback procedures } \\
\text { Structured teaching } \\
\text { Active teaching } \\
\text { Active learning }\end{array}$ \\
\hline $\begin{array}{l}\text { Understanding and developing } \\
\text { people }\end{array}$ & $\begin{array}{l}\text { HRM \& HRD } \\
\text { Coaches teachers } \\
\text { Recruits teachers } \\
\text { Builds consensus } \\
\text { Individual support } \\
\text { Intellectual stimulation }\end{array}$ & $\begin{array}{l}\text { Cohesion among teachers } \\
\text { Professionalisation } \\
\text { Teacher competency } \\
\text { Teachers' sense of self } \\
\text { efficacy }\end{array}$ \\
\hline Redesigning the organisation & $\begin{array}{l}\text { Uses 'substitutes' for leadership } \\
\text { Distributes leadership tasks } \\
\text { Creates climate }\end{array}$ & $\begin{array}{l}\text { Student monitoring \& } \\
\text { feedback provisions } \\
\text { Disciplinary climate } \\
\text { Supportive climate }\end{array}$ \\
\hline
\end{tabular}

\section{Results of earlier meta-analyses \\ Results}

Meta-analyses provide a quantitative synthesis of research results from individual studies. In meta-analysis the findings are reported in terms of effect sizes (representing both the direction and magnitude of the effect). Although there are many different types of effect size measures, two main types often used are correlations and standardised mean differences. In school effectiveness research, effect sizes reflect the association of a particular effectiveness enhancing variable (in our case leadership) with an effect measure, like the results on a cognitive achievement test. In the context of effectiveness research, these associations are usually rendered as correlations (indicated with the coefficient $r$, expressing the product moment correlation). In the research literature at large, effect sizes are often expressed as the standardised mean difference between an experimental and a control group (indicated with coefficient Cohen's $d$ ). The two coefficients $(r$ and $d$ ) are convertible to one another ${ }^{1}$. In this article we refer to effect sizes using both of these coefficients, although we have consistently used effect sizes expressed in correlations in the tables.

In Table 3, the results of nine meta-analyses are summarised. These meta-analyses are by Scheerens and Bosker (1997), Witziers, Bosker, and Krüger (2003), Marzano, Waters, and McNulty (2005), Chin (2007), two by Robinson, Lloyd, and Rowe (2008), Creemers and Kyriakides (2008), Scheerens et al. (2007), and Hattie (2009). ${ }^{2}$ 
Table 3. Summary of results from meta-analyses on school leadership; effect sizes are rendered as correlations between school leadership and student achievement.

\begin{tabular}{llc}
\hline Meta-analysis by: & \multicolumn{1}{c}{ Leadership concept } & $\begin{array}{c}\text { Effect size } \\
\text { (correlation) }\end{array}$ \\
\hline Scheerens and Bosker (1997) & School leadership & $r=0.04$ \\
Witziers, Bosker, and Krüger (2003) & School leadership & $r=0.02$ \\
Marzano, Waters, and McNulty (2005) & Generalised school leadership & $r=0.25$ \\
Chin (2007) & Transformational leadership & $r=0.49$ \\
Robinson, Lloyd, and Rowe (2008) (1) & Instructional leadership & $r=0.21$ \\
Robinson, Lloyd, and Rowe (2008) (2) & Transformational leadership & $r=0.06$ \\
Creemers and Kyriakides (2008) & School leadership & $r=0.07$ \\
Hattie (2009) & School leadership & $r=0.18$ \\
Scheerens et al. (2007) & School leadership & $r=0.06$
\end{tabular}

The average effect size across these meta-analyses comes down to $r=0.15$. When leaving out the outlying value of the meta-analysis by Chin the average effect size would become $r=0.11$.

In our own work we consistently find effect sizes in the order of $r=0.05$, while some other meta-analyses have found much higher effect sizes. We have no clear explanation for this fact.

\section{Interpretation of effect sizes}

According to Cohen's standards for interpreting effect sizes $^{3}$, our results on leadership effects should be interpreted as negligible to small. It should be noted however, that several authors argue that Cohen's standards are to be considered as too conservative, and do not match the practical significance of malleable school variables. Richard, Bond, and Stokes-Zoota (2003, cited by Baumert, Lüdtke, and Trautwein 2006) found a mean correlation of $r=0.21$ in their meta-analysis of metaanalyses in social psychology, and proposed a modification of Cohen's classification, considering a correlation of 0.30 to indicate a large effect (339). Baumert, Lüdtke, and Trautwein (2006) propose the learning gain during one school year as a realistic standard to express effects of schooling. They cite several studies indicating that this learning gain has the magnitude of about $d=0.30$, which would be comparable to a correlation of 0.15 . These authors also discuss a method to compute effect sizes developed by Tymms, Merrell, and Henderson (1997), which, when applied to a practical example, suggests that effect sizes of about $r=0.15$ to 0.20 (small to medium, according to Cohen's standards) would equal the learning gain in one school year, which they consider an effect of huge practical relevance. Seen in this light, the effect size of $r=0.11$ that we arrive at when we average the results summarised in Table 4, might perhaps be upgraded in its rating for practical significance. Yet, the literature on estimating year effects of schooling shows huge differences between subjects, grade levels and national contexts; with coefficients as high as 0.45 (Luyten 2007), this yardstick against which to compare leadership effects is not a very stable one. 
Given the long causal chain between leadership actions and student achievement results, small effect sizes should not really come as a surprise with the kind of research designs that were used in the majority of studies analysed. In fact it is rather the effect sizes in the order of magnitude of $r=0.40$ that should be seen as remarkable.

\section{Method}

\section{Literature search}

To identify potential relevant studies the following online databases were used: Web of Science (www.isiknowledge.com), Scopus (www.scopus.com), ERIC and Psycinfo (provided through Ebscohost). The search was carried out in November 2010 and focused on publications between 2005 and 2010. The databases were searched using the key terms that were also used in the meta-analyses published in Scheerens et al. (2007).

The databases were searched using a combination of the following groups of key terms:

- 'school effectiveness', 'education* effectiveness', 'teach* effectiveness', 'effective* teaching', 'effective instruction', 'instruction* effectiveness', 'mastery learning', 'constructivist teaching', 'mathematics instruction', 'reading instruction', 'science instruction', 'classrooms', 'mathematics teaching', 'reading teaching', 'science teaching';

- 'value added', attainment, achievement, 'learn* result*', 'learn* outcome*', 'learn* gain', 'student* progress';

- leadership, principal.

In total 303 hits were found (see Table 4). After removing the duplicate publications 255 unique publications were left.

In addition to the search in databases, volumes of the following journals were searched:

- American Educational Research Journal

- Educational Administration Quarterly

- Educational Management Administration \& Leadership

Table 4. Results literature search.

\begin{tabular}{lc}
\hline Database & Number of hits \\
\hline ERIC & 37 \\
PsycInfo & 140 \\
Scopus & 84 \\
Web of Science & 42 \\
Total & 303 \\
Duplicates & 48 \\
Total number of possible relevant publications & 255 \\
\hline
\end{tabular}


- International Journal of Leadership in Education

- Journal of Educational Administration

- Leadership and Policy in Schools

- School Leadership \& Management

- School Effectiveness and School Improvement

Finally, recent reviews and books on school leadership and school effectiveness, as well as references in recent articles were checked in order to find additional literature.

\section{Selection of studies for the meta-analysis}

The first selection of the studies collected was guided by the following selection criteria:

(1) Independent variable: The study is designed explicitly to examine school leadership.

(2) Dependent variable: The study had to include an explicit measure of cognitive student achievement.

(3) Language of the publication: Publications included had to be written in English or Dutch. Databases and journals other than primarily English were not searched.

(4) Study population: The study had to be conducted at primary and/or secondary school level (for students aged 4-18).

(5) Year of publication: The study is published or presented not earlier than January 2005 and before January 2011.

(6) Methods: Studies had to contain empirical data and outcomes.

Titles and abstracts of publications were evaluated on the six selection criteria. Using the above-mentioned selection criteria 80 publications remained for further evaluation.

Each of these publications was examined in full. After this second round, 25 publications were selected for meta-analysis. Of these 25 studies that met the selection criteria 10 used direct- and 15 used indirect-effect models. This article only discusses the analyses of the 15 publications published between 2005 and 2010 which used indirect-effect models. Six studies examined indirect effects of leadership in primary school contexts, four in secondary schools and five studies included both primary and secondary schools.

Six studies were conducted in the US, four in Canada, two in the Flemish Community of Belgium and one each in England and the Netherlands. One study was based on data from 14 OECD countries participating in TIMSS 2007.

The 15 studies contained 34 replications, for which effect sizes were considered, where a replication represents each association of a leadership variable, intermediary variables and a specific outcome measure. So, for example, a study that investigates leadership effects for reading and mathematics achievement would have two replications.

In all studies, structural equation modelling was used to examine the direct and indirect effects of leadership on achievement. In almost all studies, the design 
included control for student background effects, either through the use of gain scores or covariates.

\section{Calculation of effect sizes}

The number of studies and replications was considered too small to carry out a metaanalysis following the method we had employed in earlier studies, using multilevel analysis (Scheerens and Bosker 1997; Scheerens et al. 2007), based on analysis techniques as described in Raudenbush and Bryk (1985) and Hox (2002).

For each replication the total effects were copied from the publication, whenever possible. In case these total effects were not explicitly published, they were computed from the path diagrams in the publications. The individual effect of a single path is computed by multiplying all effects included in that path. There may be (usually minor) differences between published total effects and total effects computed from the diagram, especially where the path diagrams only mention significant effects.

Non-weighted and weighted total effect sizes were calculated. The relative weight for each effect size was calculated based on the sample size, which in our case was determined by the number of schools included in each sample. In this meta-analysis sample sizes ranged from 38 to 363 schools (see Table 5).

\section{Results $^{4}$}

Table 5 summarises the total effects of all 34 replications, found in 15 publications. The mean magnitude of the non-weighted total effects equals $r=0.031$, which does not deviate significantly from zero, given a standard error of 0.20 . The weighted summary effect is $r=0.048$.

However, when the outlying publication from Ten Bruggencate (2009) is excluded $^{5}$, the non-weighted mean effect size would become $r=0.060$, which deviates significantly from zero with a standard error of 0.18 . The weighted mean is almost equal to the non-weighted mean: $r=0.061$. This shows that including or excluding one publication can largely affect the conclusions, given the limited number of replications.

\section{Total effects}

Studies in which relatively high effect sizes were found are those by Leithwood and Jantzi (2008), Leithwood and Mascall (2008), and Heck and Moriyama (2010).

In almost all indirect studies the measurement of school leadership includes aspects of transformational leadership, and in half of these studies also instructional leadership. A more detailed description of the way school leadership was operationalised in these studies is provided in Hendriks and Steen (2012).

These results confirm earlier patterns of outcomes, where leadership studies conducted in North America and Australia tend to show somewhat higher effects than studies in European countries (Scheerens and Bosker 1997; Witziers, Bosker, and Krüger 2003). 
Table 5. Summary of total effects sizes in indirect effect studies.

\begin{tabular}{|c|c|c|c|c|c|}
\hline Author and year & Leadership measure & Achievement measure & $\begin{array}{l}\text { Total } \\
\text { effect }\end{array}$ & $\begin{array}{l}\text { No. of } \\
\text { schools }\end{array}$ & $\begin{array}{l}\text { Relative } \\
\text { weight }\end{array}$ \\
\hline \multirow[t]{2}{*}{ Day et al. (2009) } & $\begin{array}{l}\text { Integrated leadership } \\
\text { (primary level) }\end{array}$ & $\begin{array}{l}\text { Change in pupil outcomes over three } \\
\text { years }\end{array}$ & 0.001 & 363 & 7.51 \\
\hline & $\begin{array}{l}\text { Integrated leadership } \\
\text { (secondary level) }\end{array}$ & Idem & 0.04 & 309 & 6.4 \\
\hline \multirow[t]{2}{*}{ De Maeyer et al. (2007) } & Integrated leadership & Reading & -0.02 & 47 & 0.97 \\
\hline & Idem & Math & -0.16 & 47 & 0.97 \\
\hline \multirow[t]{2}{*}{ Heck and Hallinger (2009) } & Initial distributed leadership & Growth Rate Math & 0.03 & 195 & 4.04 \\
\hline & Change in leadership & Idem & 0.09 & 195 & 4.04 \\
\hline \multirow[t]{4}{*}{ Heck and Hallinger (2010) } & Distributed leadership & Initial Reading scores (year 2) & 0.02 & 197 & 4.08 \\
\hline & Idem & Initial Math scores (year 2) & 0.02 & 197 & 4.08 \\
\hline & Change in leadership & Growth Rate Reading & 0.10 & 197 & 4.08 \\
\hline & Idem & Growth Rate Math & 0.10 & 197 & 4.08 \\
\hline \multirow[t]{2}{*}{ Heck and Moriyama (2010) } & Collaborative leadership & Added Year Effect Reading & 0.16 & 198 & 4.1 \\
\hline & Idem & Added Year Effect Math & 0.14 & 198 & 4.1 \\
\hline Leithwood and Jantzi (2008) & $\begin{array}{l}\text { Integrated leadership: } \\
\text { School leadership }\end{array}$ & $\begin{array}{l}\text { Proportion of students reading or } \\
\text { exceeding the state's proficient level }\end{array}$ & 0.24 & 79 & 1.64 \\
\hline \multirow{3}{*}{$\begin{array}{l}\text { Leithwood, Jantzi, and } \\
\text { McElherton-Hopkins (2006) } \\
\text { Leithwood and Mascall (2008) }\end{array}$} & School leadership & 2-year mean achievement score & 0.11 & 88 & 1.82 \\
\hline & Idem & 2-year mean achievement gain & -0.06 & 88 & 1.82 \\
\hline & Collective leadership & $\begin{array}{l}\text { Percentage of students meeting or } \\
\text { exceeding the proficiency level on } \\
\text { language and math tests }\end{array}$ & 0.24 & 90 & 1.86 \\
\hline \multirow[t]{2}{*}{$\begin{array}{l}\text { Leithwood, Patten, and Jantzi } \\
\text { (2010) }\end{array}$} & Distributed leadership & $\begin{array}{l}\text { Percentage of students per school } \\
\text { achieving level } 3 \text { or higher at math } \\
\text { and literacy test }\end{array}$ & 0.11 & 199 & 4.12 \\
\hline & Idem & Idem & 0.15 & 199 & 4.12 \\
\hline
\end{tabular}


Table 5. (Continued.)

\begin{tabular}{|c|c|c|c|c|c|}
\hline Author and year & Leadership measure & Achievement measure & $\begin{array}{l}\text { Total } \\
\text { effect }\end{array}$ & $\begin{array}{l}\text { No. of } \\
\text { schools }\end{array}$ & $\begin{array}{l}\text { Relative } \\
\text { weight }\end{array}$ \\
\hline \multirow[t]{2}{*}{$\begin{array}{l}\text { Louis, Dretzke, and Wahlstrom } \\
\text { (2010) }\end{array}$} & Instructional leadership & $\begin{array}{l}\text { Percentage of students at school level } \\
\text { meeting or exceeding the proficiency } \\
\text { level } 2005 \text { math tests }\end{array}$ & 0.05 & 106 & 2.2 \\
\hline & Shared leadership & Idem & 0.03 & 106 & 2.2 \\
\hline $\begin{array}{l}\text { Opdenakker and Van Damme } \\
\text { (2007) }\end{array}$ & $\begin{array}{l}\text { Participative professionally } \\
\text { oriented leadership }\end{array}$ & Math & 0.002 & 57 & 1.18 \\
\hline Ross and Gray (2006) & Transformational leadership & Composite school score & 0.22 & 205 & 4.25 \\
\hline \multirow{2}{*}{$\begin{array}{l}\text { Supovitz, Sirinides, and May } \\
\text { (2010) }\end{array}$} & Principal leadership & English Language \& Arts & 0.03 & 38 & 0.79 \\
\hline & Idem & Math & -0.009 & 38 & 0.79 \\
\hline \multirow[t]{6}{*}{ Ten Bruggencate (2009) } & $\begin{array}{l}\text { Leadership style: Rational } \\
\text { goals (teacher perceptions) }\end{array}$ & Average exam mark & -0.16 & 97 & 2.01 \\
\hline & $\begin{array}{l}\text { Leadership style: Internal } \\
\text { Process (teacher perceptions) }\end{array}$ & Idem & 0.003 & 97 & 2.01 \\
\hline & $\begin{array}{l}\text { Leadership style: Human } \\
\text { relations (teacher } \\
\text { perceptions) }\end{array}$ & Idem & 0.004 & 97 & 2.01 \\
\hline & $\begin{array}{l}\text { Leadership style: Open } \\
\text { systems (teacher } \\
\text { perceptions) }\end{array}$ & Idem & -0.18 & 97 & 2.01 \\
\hline & $\begin{array}{l}\text { Leadership style: Rational } \\
\text { goals (principal perceptions) }\end{array}$ & Idem & 0.002 & 97 & 2.01 \\
\hline & $\begin{array}{l}\text { Leadership style: Open } \\
\text { systems (principal } \\
\text { perceptions) }\end{array}$ & Idem & -0.31 & 97 & 2.01 \\
\hline $\begin{array}{l}\text { Ten Bruggencate, Luyten, and } \\
\text { Scheerens (2010) }\end{array}$ & $\begin{array}{l}\text { Time spent on instructional } \\
\text { leadership }\end{array}$ & Math (TIMSS) & 0.02 & $\begin{array}{l}\text { Varies from } 67 \text { in } \\
\text { Cyprus to } 239 \text { in US } \\
\text { (average }=154)\end{array}$ & 3.18 \\
\hline
\end{tabular}


Table 5. (Continued.)

\begin{tabular}{|c|c|c|c|c|c|c|}
\hline Author and year & Leadership measure & & Achievement measure & $\begin{array}{l}\text { Total } \\
\text { effect }\end{array}$ & $\begin{array}{l}\text { No. of } \\
\text { schools }\end{array}$ & $\begin{array}{l}\text { Relative } \\
\text { weight }\end{array}$ \\
\hline & $\begin{array}{l}\text { Time spent on } \\
\text { administrative duties }\end{array}$ & Idem & & -0.09 & Idem, average $=154$ & 3.18 \\
\hline & $\begin{array}{l}\text { Time spent on supervising } \\
\text { teachers }\end{array}$ & Idem & & 0.09 & Idem, average $=154$ & 3.18 \\
\hline & $\begin{array}{l}\text { Time spent on public } \\
\text { relations }\end{array}$ & Idem & & 0.04 & Idem, average $=154$ & 3.18 \\
\hline Mean (non-weighted) & $\begin{array}{l}15 \text { publications; } 34 \text { effect } \\
\text { measures }\end{array}$ & & & 0.031 & & \\
\hline SE mean & & & & $(0.020)$ & & \\
\hline Mean (weighted) & & & & 0.048 & & \\
\hline \multicolumn{7}{|l|}{ without Ten Bruggencate (2009) } \\
\hline Mean (non-weighted) & $\begin{array}{l}14 \text { publications; } 28 \text { effect } \\
\text { measures }\end{array}$ & & & 0.060 & & \\
\hline SE mean & & & & $(0.018)$ & & \\
\hline Mean (weighted) & & & & 0.061 & & \\
\hline
\end{tabular}




\section{Promising paths and intermediate variables in indirect-effect models}

In Table 6, an overview is given of the most promising paths in the indirect models reviewed in this study. The combined effects represent the product of the association of leadership with a particular intermediate variable and the association of the intermediate variable and student outcomes. Remarkable outcomes are the negative paths in the studies by De Maeyer et al. (2007) and Ten Bruggencate (2009). Negative associations are sometimes interpreted as compensatory action of schools and school leaders as a reaction to low student performance, but these interpretations are rather speculative given the correlational nature of the studies in question. Combined effects range from $r=0.32-0.25$, with academic climate and instructional practices as the most promising intermediary variables, as far as the size of the combined effects is concerned.

In Table 7, the intermediate variables in promising paths of the indirect-effect models are grouped according to the four core leadership functions, included in the conceptual introduction (Table 2).

Quite a few studies address several of the core functions. The overview in Table 6 shows that intermediate variables used in the studies by Heck and Hallinger (2009, 2010), Leithwood and Jantzi (2008) and Leithwood, Patton, and Jantzi (2010) cover a broad spectrum of effectiveness enhancing school factors.

In other studies, the intermediate variables were more focused on specific effectiveness enhancing variables. In the study by De Maeyer et al. (2007), the intermediate variable academic climate was limited to climate and values (high expectations and shared sense of purpose among teachers). In the study by Ten Bruggencate et al. (2010), the way students valued mathematics and topic coverage were used as intermediate variables.

In the study by Louis, Dretzke, and Wahlstrom (2010), two intermediate variables were used: focussed instruction and teachers' professional community. Focussed instruction is targeted at aspects of indirect and constructivist teaching. Teachers' professional community is a variable in which several subcategories with regard to professional capacity of the staff (HRM and HRD) and climate are combined.

Intermediate variables covering aspects of teaching are included to a limited extent in the publications examined; only three studies (Heck and Moriyama 2010; Louis, Dretzke, and Wahlstrom 2010; Supovitz 2008) included teaching variables.

When comparing the theoretically derived intermediary conditions from Table 2 , with those that were found in our review and are listed in the second column of Table 7, we can conclude that they can indeed be subsumed under the four key leadership emphases. Next, there is a fair correspondence between the conditions from school effectiveness research and the intermediary variables used in our indirect leadership effect studies.

The data on promising indirect paths to leadership effects are still too limited to draw strong conclusions about the relative importance of the intermediary variables. The results summarised in Table 7 suggest that each of the four sets of intermediary conditions (labelled under the headings of setting directions, developing people, developing the organisation and managing the teaching and learning programme) could play a role in explaining indirect school leadership effects. Yet, a more specific connection to instructional effectiveness seems to be a promising direction, as 
Table 6. The most relevant paths found in indirect-effect models.

\begin{tabular}{|c|c|c|c|c|}
\hline Author and year & Leadership measure & Achievement measure & Intermediate variables & $\begin{array}{l}\text { Combined effect } \\
\text { via this path }\end{array}$ \\
\hline Day et al. (2009) & $\begin{array}{l}\text { Integrated leadership } \\
\text { (secondary level) }\end{array}$ & $\begin{array}{l}\text { Change in pupil outcomes over three } \\
\text { years }\end{array}$ & $\begin{array}{l}\text { Leadership Distribution in the } \\
\text { school }\end{array}$ & 0.04 \\
\hline \multirow[t]{3}{*}{ De Maeyer et al. (2007) } & Integrated leadership & Reading & none & -0.27 \\
\hline & Integrated leadership & Reading & Academic climate & 0.25 \\
\hline & Integrated leadership & Math & none & -0.15 \\
\hline \multirow{2}{*}{$\begin{array}{l}\text { Heck and Hallinger } \\
\text { (2009) }\end{array}$} & Initial distributed leadership & Growth Rate Math & Change in Capacity & 0.03 \\
\hline & Change in leadership & Growth Rate Math & Change in Capacity & 0.08 \\
\hline \multirow{4}{*}{$\begin{array}{l}\text { Heck and Hallinger } \\
\text { (2010) }\end{array}$} & Distributed leadership & Initial Reading scores (year 2) & School capacity & 0.02 \\
\hline & Distributed leadership & Initial Math scores (year 2) & School capacity & 0.02 \\
\hline & Change in leadership & Growth Rate Reading & Change in Capacity & 0.10 \\
\hline & Change in leadership & Growth Rate Math & Change in Capacity & 0.13 \\
\hline \multirow{2}{*}{$\begin{array}{l}\text { Heck and Moriyama } \\
\text { (2010) }\end{array}$} & Collaborative leadership & Added Year Effect Reading & Instructional Practices & 0.16 \\
\hline & Collaborative leadership & Added Year Effect Math & Instructional Practices & 0.14 \\
\hline $\begin{array}{l}\text { Leithwood and Jantzi } \\
\text { (2008) }\end{array}$ & $\begin{array}{l}\text { Integrated leadership: } \\
\text { School leadership }\end{array}$ & $\begin{array}{l}\text { Proportion of students reaching or } \\
\text { exceeding the state's proficient level }\end{array}$ & School conditions & 0.24 \\
\hline Leithwood, Jantzi, and & School leadership & 2-year mean achievement score & (not reported) & 0.11 \\
\hline $\begin{array}{l}\text { McElherton-Hopkins } \\
\text { (2006) }\end{array}$ & Idem & 2-year mean achievement gain & (not reported) & -0.06 \\
\hline $\begin{array}{l}\text { Leithwood and Mascall } \\
\text { (2008) }\end{array}$ & Collective leadership & $\begin{array}{l}\text { Percentage of students meeting or } \\
\text { exceeding the proficiency level on } \\
\text { language and math tests }\end{array}$ & (not reported) & 0.24 \\
\hline $\begin{array}{l}\text { Leithwood, Patten, and } \\
\text { Jantzi (2010) }\end{array}$ & Distributed leadership & $\begin{array}{l}\text { Percentage of students per school } \\
\text { achieving level } 3 \text { or higher at math and } \\
\text { literacy test }\end{array}$ & $\begin{array}{l}\text { not clear from publication } \\
\text { (model } 1 \text { ) }\end{array}$ & 0.11 \\
\hline
\end{tabular}


Table 6. (Continued.)

\begin{tabular}{|c|c|c|c|c|}
\hline Author and year & Leadership measure & Achievement measure & Intermediate variables & $\begin{array}{l}\text { Combined effect } \\
\text { via this path }\end{array}$ \\
\hline & Distributed leadership & Idem & $\begin{array}{l}\text { not clear from publication } \\
\text { (model 2) }\end{array}$ & 0.15 \\
\hline \multirow[t]{3}{*}{$\begin{array}{l}\text { Louis, Dretzke, and } \\
\text { Wahlstrom (2010) }\end{array}$} & Instructional leadership & $\begin{array}{l}\text { Percentage of students at school level } \\
\text { meeting or exceeding the proficiency } \\
\text { level } 2005 \text { math tests }\end{array}$ & Focussed instruction & 0.03 \\
\hline & Instructional leadership & Idem & $\begin{array}{l}\text { Professional Community \& } \\
\text { Focussed instruction }\end{array}$ & 0.02 \\
\hline & Shared leadership & Idem & $\begin{array}{l}\text { Professional Community \& } \\
\text { Focussed instruction }\end{array}$ & 0.03 \\
\hline \multirow[t]{3}{*}{ Ross and Gray (2006) } & Transformational leadership & Composite school score & $\begin{array}{l}\text { Teacher commitment to School } \\
\text { Mission }\end{array}$ & 0.13 \\
\hline & Transformational leadership & Composite school score & $\begin{array}{l}\text { Collective Teacher efficacy \& } \\
\text { Teacher commitment to } \\
\text { Community Partnerships }\end{array}$ & 0.12 \\
\hline & Transformational leadership & Composite school score & $\begin{array}{l}\text { Teacher commitment to } \\
\text { Professional Community }\end{array}$ & -0.07 \\
\hline $\begin{array}{l}\text { Supovitz, Sirinides, and } \\
\text { May (2010) }\end{array}$ & Principal leadership & English Language \& Arts & Change in Instruction & 0.02 \\
\hline \multirow[t]{3}{*}{ Ten Bruggencate (2009) } & $\begin{array}{l}\text { Leadership style: Rational } \\
\text { goals } \\
\text { (teacher perceptions) }\end{array}$ & Average exam mark & none & -0.16 \\
\hline & $\begin{array}{l}\text { Leadership style: Open } \\
\text { systems (teacher perceptions) }\end{array}$ & Average exam mark & none & -0.18 \\
\hline & $\begin{array}{l}\text { Leadership style: Open } \\
\text { systems (principal } \\
\text { perceptions) }\end{array}$ & Average exam mark & none & -0.32 \\
\hline
\end{tabular}


Table 6. (Continued.)

\begin{tabular}{|c|c|c|c|c|}
\hline Author and year & Leadership measure & Achievement measure & Intermediate variables & $\begin{array}{l}\text { Combined effect } \\
\text { via this path }\end{array}$ \\
\hline \multirow[t]{8}{*}{$\begin{array}{l}\text { Ten Bruggencate et al. } \\
\text { (2010) }\end{array}$} & $\begin{array}{l}\text { Time spent on instructional } \\
\text { leadership }\end{array}$ & Math achievement & Valuing Math & 0.02 \\
\hline & $\begin{array}{l}\text { Time spent on administrative } \\
\text { duties }\end{array}$ & Math achievement & none & -0.04 \\
\hline & $\begin{array}{l}\text { Time spent on administrative } \\
\text { duties }\end{array}$ & Math achievement & Valuing Math & -0.02 \\
\hline & $\begin{array}{l}\text { Time spent on administrative } \\
\text { duties }\end{array}$ & Math achievement & Topic coverage (OTL) & -0.03 \\
\hline & $\begin{array}{l}\text { Time spent on supervising } \\
\text { teachers }\end{array}$ & Math achievement & none & 0.04 \\
\hline & $\begin{array}{l}\text { Time spent on supervising } \\
\text { teachers }\end{array}$ & Math achievement & Valuing Math & 0.01 \\
\hline & $\begin{array}{l}\text { Time spent on supervising } \\
\text { teachers }\end{array}$ & Math achievement & Topic coverage (OTL) & 0.03 \\
\hline & $\begin{array}{l}\text { Time spent on public } \\
\text { relations }\end{array}$ & Math achievement & Topic coverage (OTL) & 0.04 \\
\hline
\end{tabular}

Bruggencate et al.

leadership

Time spent on administrative

Time spent on administrative Math achievemen

Time spent on supervising Math achievement

Time spent on supervising Math achievement

Time spent on supervising Math achievement

Time spent on public Math achievemen 
Table 7. Connection between leadership emphases and intermediary conditions.

Leadership emphasis

(Leithwood)

Main categories of intermediary conditions

Setting directions

Academic climate

Academic climate (De Maeyer et al. 2007)

Teacher Commitment to the school mission (Ross and

Gray 2006)

Developing people

Professional capacity of the staff, cooperation and commitment of staff

Change in school academic capacity (Heck and Hallinger 2009)

Change in school improvement capacity (Heck and

Hallinger 2010)

School instructional practices (Heck and Moriyama 2010)

School conditions (Leithwood and Jantzi 2008)

Teacher's professional community (Louis, Dretzke, and

Wahlstrom 2010)

Redesigning the organisation Organisational capacity

Collective teacher efficacy (Ross and Gray 2006)

School conditions (Leithwood and Jantzi 2008)

Teacher commitment to the school as a professional community (Ross and Gray 2006)

Leadership Distribution in the school (Day et al. 2009)

Instructional conditions

Managing the teaching and

School instructional practices (Heck and Moriyama 2010)

learning programme

Focussed instruction (Louis, Dretzke, and Wahlstrom

2010)

Change in instruction (Supovitz 2008)

Topic coverage (Ten Bruggencate et al. 2010)

School conditions (Leithwood and Jantzi 2008)

'Rational Path', including academic press and disciplinary climate (Leithwood, Patten, and Jantzi 2010)

illustrated particularly in the studies by Heck and Moriyama (2010), Louis, Dretzke, and Wahlstrom (2010), and Ten Bruggencate et al. (2010). Heck and Moriyama $(2010,397)$ report that they:

... found support for [their] temporal ordering of leadership, instructional practices, and added-year effects, net of the context and social composition of the school. More specifically, stronger perceptions about leadership for learning (e.g. broad participation in improvement efforts, ongoing evaluation) were related to subsequent stronger views about the quality of instructional practices (i.e. teaching activities, learning environment) which in turn positively influenced added-year effects.

These outcomes match key assumptions of integrated educational effectiveness models, where conditions at school level are seen as relevant to the extent that they support and facilitate conditions at classroom level. As Heck and Moryiama conclude: 'The results provide support concerning the relevance of school leadership 
as a means of facilitating school improvement through building instructional practices in the school' $(2010,397)$.

Further quantitative and qualitative work would be needed to strengthen the knowledge base on indirect leadership effect models and obtain more detailed information on how the respective intermediary conditions work (and possibly interact) in influencing student achievement. A semi-structured qualitative approach, for instance, might take the available research results and operational definition of the key intermediary variables as a starting point for qualitative reflection of acting school leaders, in order to better understand the way they perceive indirect causation in their work.

\section{Discussion, school leadership as meta control}

When examining the results of school leadership effect studies over almost three decades we find rather small direct and indirect leadership effects. Theoretical work on the school as an organisation clarifies why we should not have expected high leadership effects in the first place. We have noted that in the development of school leadership concepts over time the notion that schools have many 'substitutes' for leadership has been re-discovered, and in some recent studies of distributed and organisational leadership, focused action of one central leader has practically disappeared from the scene. The theoretical work and results of empirical studies highlighted in our study suggest that, in 'normal' situations of average schools a 'lean' kind of management might be sufficient, which would make maximum use of the available substitutes and self-organisation offered by the school staff and other provisions. This kind of management fits the concept of 'meta control', which could be interpreted as orchestrating the control by the other actors on the school scene.

The concept of meta control originates from control theory (De Leeuw 1990). According to his 'control paradigm', four major types of direct control can be distinguished: routine control, adaptive control, goal control and environmental control. Routine control is about the day-to-day monitoring of an organisation's primary process. In the case of schools, under normal circumstances, very little monitoring of teachers and teaching is required. The narrow interpretation of instructional leadership is close to this kind of routine control. Meta control directed at this kind of routine control could be seen as creating favourable conditions for teachers to do their work independently. It could mean that, on the one hand, the school leader protects teachers against disturbing external influences (buffering) and, on the other hand provides facilitation in the sense of opportunities for professional development, alignment among staff, feedback, and provision of the necessary teaching resources. Taking care of and overseeing administrative and clerical tasks of the school could be seen as part of the buffering function as well. Adaptive control refers to the supervision and change of the organisation's structure and core processes. Creation of new structures for teacher cooperation and the school-wide adoption of specific ICT applications are examples of adaptive control. Alignment versus loose coupling is the theoretical issue that is at stake here (cf. Elmore 2000). Meta control directed at organisational structures and key processes is close to the management of change and transformational leadership. A school leader as a metacontroller would also need to oversee the pros and cons of structural school reform, as compared to 'simply' optimising normal functioning (routine control). Similarly, 
adaptively oriented meta control would have to strike a balance between supportive, routine and innovative aspects of the functioning of the organisation. Goal control has to do with upholding performance standards and soliciting agreement on the core objectives of the organisation. Goal control as meta control recognises that, within the controlled system, in our case the school's sub-units (i.e. teachers) have their own goals. In this case the meta-controller has a task in coordinating the individual goals and uniting them under a common school mission. This kind of goal control is close to the extended view of instructional leadership, and to transformational leadership. In environmental control, leaders influence the functioning of the organisation by means of putting into play the stimulants from the environment. This role of leadership becomes more important as schools are increasingly operating in networks or as part of higher-level organisations, such as school districts.

In short, school leaders as meta-controllers need to have a broad overview of key areas of organisational functioning, a keen eye for self-steering and self-organisation and a detached attitude to taking matters in their own hand (diverting from meta-, to direct control).

\section{Acknowledgements}

The research published in this article was supported by a grant from the Knowledge Directorate of the Dutch Ministry of Education.

\section{Notes}

1. Converting from $r$ to $d$ (Borenstein et al. 2009, 48), is as follows:

$$
d=\frac{2 r}{\sqrt{1-r^{2}}}
$$

2. Hattie presents effect sizes in terms of the standardised mean difference between experimental and control group, which are roughly twice the size of the correlation coefficient for low to medium effect sizes.

3. According to Cohen (1988), small effects are in the order of $r=0.10$, medium effects $r=$ 0.30 and large effects $r=0.50$ or higher.

4. The complete overview of results, including direct, indirect and total effects for all replications is available in a set of tables that can be obtained from the authors.

5. This study showed some highly negative effects $(-0.31,-0.18$ and -0.16 , respectively) and on the other hand more replications (6) than all other publications in the table.

\section{Notes on contributors}

Dr. Maria Hendriks is an assistant professor at the Department of Educational Sciences at the University of Twente, the Netherlands. Her research focuses on school self-evaluation, quality evaluation and educational innovation. She has participated in many EU and OECD funded research projects. Currently she is working on meta-analyses and review studies in the area of school effectiveness.

Prof. Dr. Jaap Scheerens is Professor emeritus at the University of Twente, where he led the Department of Educational Organization and Management. He has been a project leader of numerous international research projects funded by the European Union, and a consultant for international organisations like OECD, UNESCO and the World Bank. His publications are 
in the areas of school management, decentralisation in education, school effectiveness, and educational evaluation and monitoring.

\section{References}

\section{General}

Baumert, J., O. Lüdtke, and U. Trautwein. 2006. Interpreting Effect Sizes in Large-Scale Educational Assessments. Berlin: Max Planck Institute for Human Development.

Bolman, L. G., and T. E. Deal. 1997. Reframing Organizations: Artistry, Choice, and Leadership. 2nd ed. San Francisco, CA: Jossey-Bass.

Borenstein, M., L. V. Hedges, J. P. T. Higgins, and H. R. Rothstein. 2009. Introduction to Meta-analysis. Chichester: Wiley.

Bossert, S. T., D. C. Dwyer, B. Rowan, and G. V. Lee. 1982. "The Instructional Management Role of the Principal." Educational Administration Quarterly 18 (3): 34-64. doi:10.1177/ $0013161 X 82018003004$.

Cohen, D. K. 1988. "Teaching Practice...Plus que ça Change..." In Contributing to Educational Change: Perspectives on Research and Practice, edited by P. Jackson, 27-84. Berkeley, CA: McCutchan.

De Leeuw, A. C. J. 1990. Organisaties: Management, analyse, ontwerp en verandering: Een systeem visie [Organisations: Management, Analysis, Design and Change: A System's View]. Assen/Maastricht: Van Gorcum.

Edmonds, R. 1979. "Effective Schools for the Urban Poor." Educational Leadership 37 (1): 15-24. http://www.ascd.org/ASCD/pdf/journals/ed_lead/el_197910_edmonds.pdf

Elmore, R. 2000. Building a New Structure for School Leadership. Washington, DC: The Albert Shanker Institute.

Glatthorn, A. A. 1987. Curriculum Leadership. London: Glenview.

Glatthorn, A. A. 1997. The Principal as Curriculum Leader. Thousand Oaks, CA: Corwin Press.

Hallinger, P. 1983. "Assessing the Instructional Management Behavior of Principals." Unpublished doctoral diss., Stanford University.

Hallinger, P., and R. H. Heck. 2009. "Distributed Leadership in Schools: Does System Policy Make a Difference?" In Distributed Leadership: Different Perspectives, Studies in Educational Leadership, 7, edited by A. Harris, 101-117. London: Springer Science+Business Media B.V. doi:10.1007/978-1-4020-9737-9.

Heck, R. H., and K. Moriyama. 2010. "Examining Relationships Among Elementary Schools' Contexts, Leadership, Instructional Practices, and Added-year Outcomes: A Regression Discontinuity Approach." School Effectiveness and School Improvement 21 (4): 377-408. doi:10.1080/09243453.2010.500097.

Hendriks, M. A., and R. Steen. 2012. "Results from School Leadership Effectiveness Studies (2005-2010)." In School Leadership Effects Revisited. Review and Meta-analysis of Empirical Studies, edited by J. Scheerens, 65-129. Dordrecht: Springer Research Briefs in Education.

Hox, J. J. 2002. Multilevel Analysis: Techniques and Applications. Mahwah, NJ: Lawrence Erlbaum Associates.

Leithwood, K. 1992. "Transforming Leadership: The Move toward Transformational Leadership." Educational Leadership 49 (5): 8-12. http://www.ascd.org/ASCD/pdf/journals/ ed_lead/el_199202_leithwood.pdf

Leithwood, K., D. Jantzi, and Ch. McElheron-Hopkins. 2006. "The Development and Testing of a School Improvement Model." School Effectiveness and School Improvement 17 (4): $441-$ 464. doi:10.1080/09243450600743533.

Luyten, H. 2007. Opportunities to Utilize Already Existing Quantitative Data for PISA 2009. Discussion paper. Enschede: University of Twente.

Marks, H. M., and S. M. Printy. 2003. "Principal Leadership and School Performance: An Integration of Transformational and Instructional Leadership." Educational Administration Quarterly 39 (3): 370-397. doi:10.1177/0013161X03253412.

Mulford, B. 2003. School Leaders: Changing Roles and Impact on Teacher and School Effectiveness. Paper commissioned by the Education and Training Policy Division for the 
activity Attracting, Developing and Retaining Effective Teachers. Paris: OECD. http://www. oecd.org/dataoecd/61/61/2635399.pdf

Quinn, R. E., S. R. Faerman, M. P. Thompson, and M. R. McGrath. 1996. Becoming a Master Manager: A Competency Framework. New York: John Wiley.

Raudenbush, S., and A. Bryk. 1985. "Empirical Bayes Meta-analysis.” Journal of Educational Statistics 10 (2): 75-98. doi:10.2307/1164836.

Richard, F. D., C. F. Bond, Jr., and J. J. Stokes-Zoota. 2003. "One Hundred Years of Social Psychology Quantitatively Described.” Review of General Psychology 7 (4): 331-363. doi:10.1037/1089-2680.7.4.331.

Scheerens, J. 2000. Improving School Effectiveness. Fundamentals of Educational Planning series no. 68. Paris: UNESCO, International Institute for Educational Planning.

Scheerens, J., and R. J. Bosker. 1997. The Foundations of Educational Effectiveness. Oxford: Pergamon.

Silins, H., and B. Mulford. 2004. "Schools as Learning Organizations: Effects on Teacher Leadership and Student Outcomes." School Effectiveness and School Improvement 15 (3-4): 443-446. doi:10.1080/09243450512331383272.

Supovitz, J. A. 2008. "Instructional Leadership in American High Schools." In Effective Teacher Leadership: Using Research to Inform and Reform, edited by M. M. Mangin and S. R. Stoelinga, 144-162. New York: Teachers College Press.

Ten Bruggencate, G., H. Luyten, and J. Scheerens. 2010. Quantitative Analysis of International Data, Exploring Indirect Effect Models of School Leadership. Enschede: University of Twente.

Tymms, P., C. Merrell, and B. Henderson. 1997. "The First Year at School. A Quantitative Investigation of the Attainment and Progress of Pupils." Educational Research and Evaluation 3 (2): 101-118. doi:10.1080/1380361970030201.

\section{Meta-analyses}

Chin, J. M.-C. 2007. "Meta-analysis of Transformational School Leadership Effects on School Outcomes in Taiwan and the USA.” Asia Pacific Education Review 8 (2): 166-177. doi:10.1007/BF03029253.

Creemers, B., and L. Kyriakides. 2008. The Dynamics of Educational Effectiveness: A Contribution to Policy, Practice and Theory in Contemporary Schools. New York: Routledge.

Hattie, J. 2009. Visible Learning: A Synthesis of over 800 Meta-analyses Relating to Achievement. New York: Routledge.

Hendriks, M. A., and R. Steen. 2012. "Results from School Leadership Effectiveness Studies (2005-2010)." In School Leadership Effects Revisited. Review and Meta-analysis of Empirical Studies, edited by J. Scheerens, 65-129. Dordrecht: Springer Research Briefs in Education.

Marzano, R. J., T. Waters, and B. A. McNulty. 2005. School Leadership that Works: From Research to Results. Alexandria, VA: Association for Supervision and Curriculum Development.

Robinson, V. M. J., C. Lloyd, and K. J. Rowe. 2008. "The Impact of Leadership on Student Outcomes: An Analysis of the Differential Effects of Leadership Types." Educational Administration Quarterly 44 (5): 635-674. doi:10.1177/0013161X08321509.

Scheerens, J., and R. J. Bosker. 1997. The Foundations of Educational Effectiveness. Oxford: Pergamon.

Scheerens, J., H. Luyten, R. Steen, and Y. Luyten-de Thouars. 2007. Review and Meta-analyses of School and Teaching Effectiveness. Enschede: University of Twente.

Witziers, B., R. J. Bosker, and M. L. Krüger. 2003. "Educational Leadership and Student Achievement: The Elusive Search for an Association." Educational Administration Quarterly 39 (3): 398-425. doi:10.1177/0013161X03253411.

\section{Indirect effect studies used for meta-analyses}

Day, C., P. Sammons, D. Hopkins, A. Harris, K. Leithwood, Q. Gu, E. Brown, E. Ahtaridou, and A. Kington. 2009. The Impact of School Leadership on Pupil Outcomes. Nottingham: The National College for School Leadership.

De Maeyer, S., R. Rymenans, P. van Petegem, H. van den Bergh, and G. Rijlaarsdam. 2007. "Instructional Leadership and Pupil Achievement: The Choice of a Valid Conceptual 
Model to Test Effects in School Effectiveness Research." School Effectiveness and School Improvement 18 (2): 125-145. doi:10.1080/09243450600853415.

Heck, R. H., and P. Hallinger. 2009. "Assessing the Contribution of Distributed Leadership to School Improvement and Growth in Math Achievement." American Educational Research Journal 46 (3): 659-689. doi:10.3102/0002831209340042.

Heck, R. H., and P. Hallinger. 2010. "Testing a Longitudinal Model of Distributed Leadership Effects on School Improvement.” The Leadership Quarterly 21 (5): 867-885. doi:10.1016/ j.leaqua.2010.07.013.

Heck, R. H., and K. Moriyama. 2010. "Examining Relationships Among Elementary Schools' Contexts, Leadership, Instructional Practices, and Added-year Outcomes: A Regression Discontinuity Approach." School Effectiveness and School Improvement 21 (4): 377-408. doi:10.1080/09243453.2010.500097.

Hendriks, M. A., and R. Steen. 2012. "Results from School Leadership Effectiveness Studies (2005-2010)." In School Leadership Effects Revisited. Review and Meta-analysis of Empirical Studies, edited by J. Scheerens, 65-129. Dordrecht: Springer Research Briefs in Education.

Leithwood, K., and D. Jantzi. 2008. "Linking Leadership to Student Learning: The Contributions of Leader Efficacy.” Educational Administration Quarterly 44 (4): 496-528. doi:10.1177/0013161X08321501.

Leithwood, K., D. Jantzi, and C. McElheron-Hopkins. 2006. "The Development and Testing of a School Improvement Model." School Effectiveness and School Improvement 17 (4): 441464. doi:10.1080/09243450600743533.

Leithwood, K., and B. Mascall. 2008. "Collective Leadership Effects on Student Achievement." Educational Administration Quarterly 44 (4): 529-561. doi:10.1177/0013161X083 21221.

Leithwood, K., S. Patten, and D. Jantzi. 2010. "Testing a Conception of How School Leadership Influences Student Learning." Educational Administration Quarterly 46 (5): 671706. doi:10.1177/0013161X10377347.

Louis, K. S., B. Dretzke, and K. Wahlstrom. 2010. "How Does Leadership Affect Student Achievement? Results from a National US Survey." School Effectiveness and School Improvement 21 (3): 315-336. doi:10.1080/09243453.2010.486586.

Opdenakker, M.-C., and J. Van Damme. 2007. "Do School Context, Student Composition and School Leadership Affect School Practice and Outcomes in Secondary Education?" British Educational Research Journal 33 (2): 179-206. doi:10.1080/01411920701208233.

Ross, J. A., and P. Gray. 2006. "School Leadership and Student Achievement. The Mediating Effects of Teacher Beliefs." Canadian Journal of Education 29 (3): 798-822. doi:10.2307/ 20054196.

Supovitz, J., P. Sirinides, and H. May. 2010. "How Principals and Peers Influence Teaching and Learning." Educational Administration Quarterly 46 (1): 31-56. doi:10.1177/1094670509 353043.

Ten Bruggencate, G. 2009. Maken schoolleiders het verschil? [Do School Leaders Make a Difference?]. Enschede: University of Twente.

Ten Bruggencate, G., H. Luyten, and J. Scheerens. 2010. Quantitative Analysis of International Data, Exploring Indirect Effect Models of School Leadership. Enschede: University of Twente. 